\title{
MAKALAH
}

\section{TAHAP-TAHAP SUPERVISI PENDIDIKAN}

Diajukan untuk memenuhi tugas mata kuliah Manajemen Sekolah

Dosen Pengampu : Wahyu Bagja Sulfemi, M.Pd

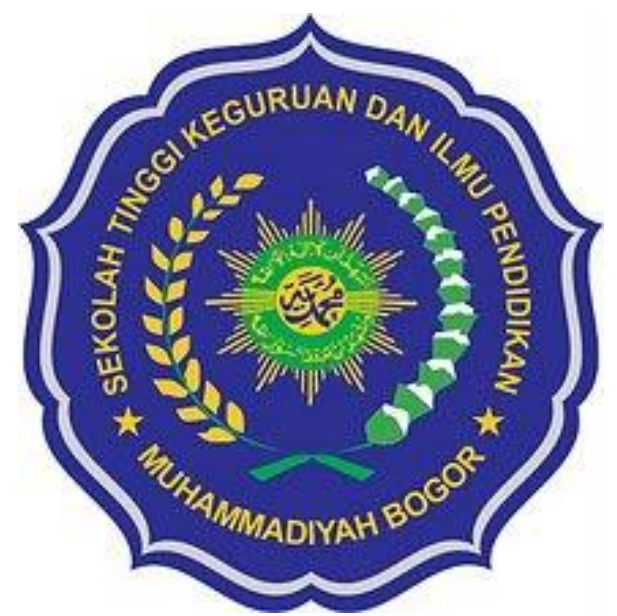

Disusun Oleh :

Lavia Agustriyani 0142S1A018014

\section{PROGRAM STUDI ADMINISTRASI PENDIDIKAN}

STKIP MUHAMMADIYAH BOGOR 


\section{Tahap-Tahap Supervisi Pendidikan}

Dalam melaksanakan tugasnya di sekolah, kepala sekolah mempunyai beberapa tanggung jawab yakni berkewajiban melaksanakan administrasi sekolah yang bertujuan menciptakan situasi belajar mengajar menjadi lebih baik dan melaksanakan supervise pendidikan sesuai dengan ketentuan yang telah ditetapkan supaya guru-guru termotivasi dalam menjalankan tugas-tugas pembelajaran dan mampu membimbing peserta didik menjadi lebih baik.

Dalam pelaksanaan tugasnya sebagai supervisor, kepala sekolah hendaknya memperhatikan beberapa pendekatan yang akan digunakannya. Pendekatan atau orientasi yang dilakukan oleh supervisor sangat tergantung pada kondisi guru. Untuk itu supervise pendidikan memerlukan berbagai pendekatan dalam mencapai tujuan, diantaranya adalah pendekatan supervise artistic, pendekatan supervise saintifik dan pendekatan supervise klinis. Pertama pendekatan supervise artistic yakni proses supervise merupakan suatu hal yang tidak bisa dijelaskan secara rasioanl.

Kreatifitas supervisor memiliki peran yang dominan didalam memperbaiki kualitas pelayanan pendidikan, pendekatan supervise saintifik merupakan suatu proses supervise yang dilaksanakan berdasarkan atas fakta dan data, sedangkan pendekatan supervise klinis lebih bersifat dalam rangka mengobati yakni penampilan guru dalam mengajar. Sebagaimana dipaparkan diatas, proses supervise pendidikan pada hakikatnya merujuk pada upaya untuk mencapai tujuan, sesuai dengan ketentuan yang telah ditetapkan sesuai keputusan bersama, dengan suasana pendukung, dan pendekatan system sesuai dengan karakteristik guru.

\section{A. Tahap-Tahap Supervisi Pendidikan}

Tahap-tahap supervisi pendidikan dibagi dalam 5 tahap :

1). Menciptakan suasana kekeluargaan yang intim atara guru dengan supervisor agar komunikasi selama kegiatan dapat berlangsung secara efektif.

2). Membuat kesepakatan antara guru dengan supervisor tentang aspek proses belajar-mengajar yang akan dikembangkan dan ditingkatkan, kedua perencanaan oleh guru dan supervisor yakni membuat perencanaan pelaksanaan obeservasi secara bersamaan. 
3). Mengenai pelaksanaan pelatihan mengajar dan observasi yang mana guru sedang melakukan proses pembelajaran sedang supervisor melakukan pengamatan secara cermat, dengan menggunakan instrument obeservasi.

4). Mengadakan analisis data, dalam hal ini supervisor mengjak guru untuk mendiskusikan apa yang telah dilaksanakan oleh guru melakukan proses pembelajaran di kelas.

5). Langkah diskusi memberikan umpan balik yang bertujuan untuk memberikan umpan balik atas apa yang telah dilakukan oleh supervisor kepada guru yang sedang berlatih mengajar meningkatkan ketrampilannya dan pelaksanaan langkah pemberian umpan balik sebaiknya dilakukan secara objektif dan segera.[1]

Kelima langkah supervise pendidikan ini mempunyai beberapa keterkaitan yang erat satu sama lain, dan berkesinambungan dalam beberapa proses langkah yang dilakukan oleh supervisor guna melakukan control terhadap pembelajaran guru di kelas. Pemaknaan atas kelima langkah supervise pendidikan tersebut hendaknya juga membina inisiatif gutu serta mendorongnya untuk aktif menciptakan suasana dimana tiap orang merasa aman dan dapat mengembangkan potensi-potensinya.

Dan seorang supervisor mampu menginterpretasikan makna demokrasi sebagai pemberi kebebasan seluas-luasnya kepada bawahan sehingga akhirnya supervisor sendiri tidak akan kehilangan otoritasnnya sebagai pengamat. Supervisor hendaknya menyerahkan atau mempercayai bawahannya untuk mengambil keputusan apa saja. Diharapkan supervise mampu menghargai pendapat dari para bawahannya ( yang disupervisi) serta bisa memberikan kepada mereka suatu solusi atau arahan untuk mengembangkan daya kreatifitasnya. Mereka bekerja sama untuk mencapai tujuan bersama. Semua keputusan diambil dengan jalan musyawarah bersama. Pelaksanaan keputusan dilakukan bersama-sama karena keputusan tersebut dirasakan telah menjadi milik berdua.

Supervisi tidaklah merupakan suatu kegiatan tunggal, akan tetapi merupakan serangkaian kegiatan yang prosesnya berjalan secara sistematis, berencana, dan teratur untuk tercapainya tujuan yang diinginkan. Untuk mencapai tujuan tersebut dalam pelaksanaannya tidak bisa terlepas dari proses inspeksi, walaupun kita tidak bersedia dan mau menerima inspeksi sebagai supervisi, akan tetapi pada hakekatnya proses supervise berjalan di atas dasar inspeksi. Hal ini tidak dapat dihindari dalam kenyataannya setiap kali pelaksanaan supervisi selalu diawali dengan kegiatan inspeksi terlebih dahulu. Dengan kata kalin inspeksi merupakan salah satu fungsi daripada supervisi. Apabila demikian, sekarang timbul pertanyaan: apakah setiap kali pelaksanaan supervisi selalu didahului dengan 
inspeksi sebelumnya? Jawaban yang dapat diberikan untuk pertanyaan tersebut dapat dilihat dari dua sisi, yaitu disatu sisi dapat kita jawab ya dan disisi lain dapat kita jawab tidak. Mari kita analisis kedua alternatif jawaban tersebut di atas.

Proses supervisi berdasarkan inspeksi, pelaksanaan kegiatan supervisi prosesnya dapat dimulai dengan mengadakan inspeksi terlebih dahulu untuk mengumpulkan berbagai data, mengolah data dengan ukuran yang telah ditentukan, dan kemudian menyusun suatu kesimpulan sebagai suatu konduite. Konduite adalah hasil penilaian sepihak yakni berdasarkan pendapat pemeriksa dengan ukuran yang ada sesuai dengan ketentuan dan peraturan yang berlaku. Apabila hasil pemeriksaan itu tidak ada tindak lanjutnya bagi pembinaan atau pengembangan kemampuan professional guru yang diperiksa, dan hanya dipakai untuk dasar kenaikan pangkat atau gaji berkala, pemindahan dan konsekuensi lainnya, maka sampai disitulah batas daripada fungsi pemeriksaan.

Tidak ada usaha peningkatan kemampuan bagi guru yang diperiksa berarti inspeksi semacam itu tidak dilakukan dalam rangka supervisi. Tetapi jika hasil inspeksi yang telah dilakukan itu dijadikan sebagai bahan masukan bagi pembinaan atau pengembangan kemampuan professional guru yang diinspeksi, maka proses semacam itu dilakukan dalam rangka supervisi. Ini berarti setiap pelaksanaan supervisi diperlukan adanya inspeksi sebelumnya.

Supervisi adalah merupakan suatu usaha pembinaan kemampuan guru agar dapat berkembang dalam jabatannya, cenderung demokratis. Oleh karena itu, apabila dimulainya proses supervisi dengan melalui persetujuan dan kerjasama yang akan disupervisi sebelumnya, tanpa diawali dengan kegiatan terlebih dahulu, maka proses supervisi ini tidak didasarkan atas inspeksi. Sesuai dengan prinsip supervisi yang lebih banyak memerlukan partisipasi dan kerjasama dengan para guru, maka supervisor dapat yang akan disupervisi untuk bersama-sama mempelajari masalah-masalah yang banyak dihadapi oleh guru-guru, bersama-sama mencari dan menemukan faktor-faktor penyebabnya, dan bersama-sama pula mencarikan cara yang efektif untuk mengatasinya melalui musyawarah mufakat untuk menemukan kesamaan.

Pendekatan supervisor semacam ini dapat dilakukan hanya dengan kegiatan sepihak saja oleh inspektur. Mengadakan observasi, kunjungan kelas, pemeriksaan, menelaah laporan saja tidaklah cukup untuk menilai seorang guru dengan segala masalahnya, tetapi diperlukan komunikasi edukatif yang langsung berhubungan dengan para guru. Karena dalam proses supervisi dengan pertemuan atau percakapan pribadi antara supervisor dengan guru dapat terjadi interaksi edukatif dan saling pengaruh mempengaruhi, ada sifat keterbukaan dan kekeluargaan yang mereka miliki dan mewarnai pertemuan itu, sehingga lebih 
memudahkan ditemukannya jalan keluar bagi pemecahan setiap masalah yang dialaminya.

Supervisi suatu proses yang siklusnya berkepanjangan tidak kunjung selesai walaupun suatu saat supervisi sudah tidak diperlukan lagi dalam dunia pendidikan, supervisi tetap ada dan berlangsung sepanjang masa ada manusia yang mau membina diri, belajar dan berkembang, kemampuannya. Supervisi tidak hanya diperlukan secara mendadak untuk sesuatu keperluan khusus, untuk penyusunan sesuatu laporan pendidikan dan sebagainya.

Kepala sekolah dalam melaksanakan fungsinya selaku supervisor harus selalu terbuka mengajak para guru untuk menemukan, menyadari dan mengakui kelemahan-kelemahannya atau kekurangan-kekurangannya sendiri tanpa ada usaha memanipulasi. Keadaan yang dialaminya untuk menjaga harga diri dan martabat sesungguhnya akan menyulitkan diri sendiri. Pendekatan yang bersifat interpersonal dalam supervisi pendidikan perlu diwujudkan oleh supervisor dan guru-guru.

Persoalan yang dihadapi adalah karena masing-masing guru mempunyai kesulitan yang unik dengan kadar masalahnya yang berbeda-beda pula, sehingga pemecahannya memerlukan pendekatan yang berbeda pula dan dengan cara sendiri-sendiri sesuai dengan jenis dan sifat masalah yang dialaminya.

Proses supervisi sebelumnya dengan perumusan sesuatu masalah yang diduga timbul dan dialami oleh guru-guru di suatu sekolah atau kelas, selanjutnya diadakanlah penelitian untuk memperoleh data/ informasi yang berhubungan dengan masalah tersebut. Hasil pengumpulan data akan dianalisis untuk menemukan kelemahan atau kekurangan daripada guru-guru tersebut dan diusahakan cara-cara yang terbaik untuk mengatasinya[2].

B. Manfaat dan Tujuan Supervisi Pendidikan

Apabila supervise dapat dilakukan dengan baik, akan diperoleh banyak manfaat. Manfaat tersebut diantaranya adalah sebagai berikut :[3]

1) Supervise dapat meningkatkan efektifitas kerja. Peningkatan efektifitas kerja ini erat hubungannya dengan peningkatan pengetahuan dan keterampilan bawahan serta makin terbinanya hubungan dan suasana kerja yang lebih harmonis antara atasan dan bawahan.

2) Supervisi dapat lebih meningkatkan efesiensi kerja. Peningkatan efesiensi kerja ini erat kaitannya dengan makin berkurangnya kesalahan yang dilakukan 
bawahan, sehingga pemakaian sumber daya (tenaga, harta dan sarana) yang sia-sia akan dapat dicegah.

Apabila kedua peningkatan ini dapat diwujudkan, sama artinya dengan telah tercapainya tujuan suatu organisasi. Tujuan pokok dari supervise ialah menjamin pelaksanaan berbagai kegiatan yang telah direncanakan secara benar dan tepat, dalam arti lebih efektif dan efesien, sehingga tujuan yang telah ditetapkan organisasi dapat dicapai dengan memuaskan.[4] 


\section{Soal dan Jawaban}

- Soal

Pilihan Ganda

1. Yang termasuk dalam tahap supervisi pendidikan adalah, kecuali ...
a. menciptakan kekeluargaan
b. tidak melakukan proses
c. pelaksanaan pelatihan
d. mengadakan analisis data
e. langkah diskusi

2. Pendekatan supervise artistic yaitu proses supervise suatu hal yang tidak bisa dijelaskan secara ...
a. emosional
b. nasional
c. ambisi
d. rasional
e. verbal

3. 1) menciptakan kekeluargaan

2) membuat kesepakatan

3) pelaksanaan pelatihan

4) mengadakan analisis data

5) langkah diskusi

Diatas merupakan ... supervisi pendidikan.
a. pengertian
b. fungsi
c. tahap
d. teknik
e. manfaat

4. Pendekatan supervisi terbagi menjadi tiga yaitu ...
a. klinis, verbal, saintik
b. saintik, artistik, verbal
c. artistik, saintik, klinis
d. antik, verbal, klinis
e. artistik, antik, verbal

5. Pendekatan yang bersifat interpersonal dalam supervise pendidikan perlu diwujudkan oleh ... dan ...
a. supervisor dan guru-guru
b. supervisor dan murid
c. guru dan murid 
d. kepala sekolah dan murid

e. penjaga dan supervisor

6. Peningkatan kerja ini erat kaitannya dengan makin berkurangnya kesalahan yang dilakukan bawahan, sehingga pemakaian sumber daya (tenaga, harta dan sarana) yang sia-sia akan dapat dicegah. Adalah pengertian dari peningkatan ...
a. efektifitas
b. efesiensi
c. usaha
d. verbal
e. modal

7. ... merupakan salah satu fungsi daripada supervisi.
a. Inspeksi
b. Efektifitas
c. Efesiensi
d. Supervisor
e. peningkatan

8. Hasil penilaian sepihak yakni berdasarkan pendapat pemeriksa dengan ukuran yang ada sesuai dengan ketentuan dan peraturan yang berlaku. Merupakan pengertian dari ...
a. tahapan
b. peran
c. fungsi
d. konduite
e. efektifitas

9. Hasil pengumpulan data akan dianalisis untuk ...
a. mengumpulkan hasil
b. memperbanyak peningkatan
c. menilai sesuai pendapat
d. mengumpulkan penilaian
e. menemukan kelemahan atau kekurangan

10. Tujuan pokok dari supervisi ialah menjamin pelaksanaan berbagai kegiatan yang telah direncanakan secara benar dan tepat, dalam arti lebih ... dan ..., sehingga tujuan yang telah ditetapkan organisasi dapat dicapai dengan memuaskan.
a. ringan dan tepat
b. efektif dan benar
c. ringan dan efesien
d. benar dan selaras
e. efektif dan efesien 
Essay

1. Supervisi pendidikan memerlukan berbagai pendekatan dalam mencapai tujuan. Sebutkan pendekatan tersebut?

2. Jelaskan tahap-tahap supervisi pendidikan!

3. Mengapa tahap supervisi pendidikan mempunyai keterkaitan erat satu sama lain?

4. Konduite itu apa. Jelaskan!

5. Sebutkan manfaat dari supervisi pendidikan?

- Jawaban

Pilihan Ganda

1. $b$

2. d

3. c

4. c

5. a

6. b

7. a

8. d

9. e

10. e

Essay

1. Pendekatan supervise artistic, Pendekatan supervise saintik, Pendekatan supervise klinis.

2. a). Menciptakan suasana kekeluargaan yang intim antara guru dengan supervisor agar komunikasi selam kegiatan dapat berlangsung secara efektif.

b). Membuat kesepakatan anata guru dengan supervisor tentang aspek proses belajar-mengajar yang akan dikembangkan dan ditingkatkan, kedua perencanaan oleh guru dan supervisor yakni membuat perencanaan pelaksnaan observasi secara bersamaan.

c). Mengenai pelaksanaan pelatihan mengajar dan observasi yang mana guru sedang melakukan proses pembelajaran sedang supervisor melakukan pengamatan secara cermat, dengan menggunakan instrument observasi.

d). Mengadakan analisis data, dalam hal ini supervisor mengajak guru untuk mendiskusikan apa yang telah dilaksanakan oleh guru melakukan proses pembelajaran di kelas. 
e). Langkah diskusi memberikan umpan balik atas apa yang telah dilakukan oleh supervisor kepada guru yang sedang berlatih mengajar meningkatkan keterampilannya dan pelaksanaan langkah pemberian umpan balik sebaiknya dilakukan secara objektif.

3. Pemaknaan atas kelima langkah supervise pendidikan tersebut hendaknya juga membina inisiatif guru serta mendorongnya unruk aktif menciptakan suasana dimana tiap orang merasa aman dan dapat mengembangkan potensi-potensinya.

4. Konduite adalah hasil penilaian sepihak yakni berdasarkan pendapat pemeriksa dengan ukuran yang ada sesuai dengan ketentuan dan peraturan yang berlaku. Apabila hasil pemeriksaan itu tidak ada tindak lanjutnya bagi pembinaan atau pengembangan kemampuan professional guru yang diperiksa, dan hanya dipakai untuk dasar kenaikan pangkat atau gaji berkala, pemindahan dan konsekuensi lainnya, maka sampai disitulah batas daripada fungsi pemeriksaan.

5. a). Supervisi dapat meningkatkan efektifitas kerja

b). Supervisi dapat lebih meningkatkan efesiensi kerja 


\section{Daftar Pustaka}

Sagala, Syaiful. 2010. Supervisi Pembelajaran: dalam Profesi Pendidikan. Bandung: Alfabeta.

Mushlih, Aguslani dan Suryadi, Rudi Ahmad. 2018. Supervisi pendidikan Teori dan Praktik. Bandung: Remaja Rosdakarya.

Purwanto, Ngalim. 2010. Administrasi dan Supervisi Pendidikan. Bandung: Remaja Rosdakarya.

[1] Piet A. Suhertian. Konsep Dasar dan Teknik Supervisi Pendidikan Dalam Rangka PengembanganSumber DayaManusia. Hal. 20

[2] Muhammad, Rifai. 1982. Administrasi dan Supervisi Pendidikan. Bandung: PT. Remaja Rosdakarya.

[3] dan [4] Suarli dan Bachtiar. 2009.

Rahmadhani032.blogspot.com/2014/10/makalah-proses-supervisipendidikan.html? $\mathrm{m}=1$ 